\title{
QUEST FOR SUITABLE STORAGE CONDITION FOR SUSTAINABLE PROCESSING QUALITY OF POTATO TUBERS
}

\author{
D. Parvin ${ }^{1}$, J. U. Ahmed ${ }^{1}$, M. M. Hossain ${ }^{2}$ and M. Mohi-Ud-Din ${ }^{1 *}$
}

\begin{abstract}
Processing quality of potato tubers depend on the physico-chemical properties which changes within the time in long-term storage period. The present study was conducted to find out a suitable storage condition that could be able to maintain the processing quality of potatoes. Three potato varieties namely Asterix (BARI Alu-25), Courage (BARI Alu29) and Lady Rosetta (BARI Alu-28) and three different storage conditions viz. Bamboo chamber $(\mathrm{BC})$, earthen chamber with evaporative cooler (EC) and refrigerator (RF) were used in this study. Data were recorded monthly-basis on the physico-chemical processing qualities of the potato tubers. Potato tubers stored in RF was able to maintain higher dry matter content and lower weight loss, shrinkage and energy content than BC and EC. Though the physical qualities of the refrigerated tubers were well-maintained, but produced considerably higher amount of mean reducing sugars $(2.69 \mathrm{mg} / \mathrm{g} \mathrm{FW})$ which was 11.6 and $17.9 \%$ higher than the mean of BC $(2.41 \mathrm{mg} / \mathrm{g} \mathrm{FW})$ and $\mathrm{EC}(2.28$ $\mathrm{mg} / \mathrm{g} \mathrm{FW})$, respectively; and higher mean sucrose contents $(2.46 \mathrm{mg} / \mathrm{g} \mathrm{FW})$ which was 6.5 and $18.8 \%$ higher than the mean of BC $(2.31 \mathrm{mg} / \mathrm{g} \mathrm{FW})$ and EC (2.07 mg/g FW), respectively. EC maintained significantly lower amount of mean glucose $(0.17 \mathrm{mg} / \mathrm{g}$ FW), fructose (1.96 mg/g FW) and total soluble sugar $(4.20 \mathrm{mg} / \mathrm{g} \mathrm{FW})$ contents than BC and RF. Compared to pre-storage, mean reducing sugar content was increased by $1.5,1.7$ and 2.0 times in $\mathrm{EC}, \mathrm{BC}$ and RF, respectively until 90 days of storage and the increase in mean sucrose content was 1.7-, 2.1- and 2.3-fold in EC, BC and RF, respectively. Among the varieties, Courage and Lady Rosetta were suitable for long-term storage for processing than Asterix. Chips produced from the potatoes stored in the EC acquired significantly higher scores for sensory attributes than that of BC and RF. Results clearly depicted that potatoes stored in EC were more suitable for processing due to moderate retention of dry matter content $(22.13 \%)$ and lower accumulation of different sugars and were able to retain processing quality up to 90 days of storage than that of $\mathrm{BC}$ and $\mathrm{RF}$.
\end{abstract}

Keywords: Evaporative cooler, earthen chamber, bamboo chamber, reducing sugar, sucrose.

\section{Introduction}

Potato (Solanum tuberosum L.) is the most important food crop in the world after wheat, rice and maize. In Bangladesh, potato is a prominent crop in consideration of production and its internal demand. The potato area and yield rate has significantly increased, which contributed $7.83 \%$ increase in total volume of production (BBS, 2018). But the storage

\footnotetext{
${ }^{1}$ Department of Crop Botany, Bangabandhu Sheikh Mujibur Rahman Agricultural University, Gazipur 1706, ${ }^{2}$ Department of Horticulture, Bangabandhu Sheikh Mujibur Rahman Agricultural University, Gazipur 1706, Bangladesh. *Corresponding author: mmu074@bsmrau.edu.bd
} 
facilities of the country are not sufficient for this increased produce. Due to inadequate cold storage facilities to hold the produce for longer periods, large quantities are spoiled before they could be consumed (Hossain and Mia, 2009). There are about 390 cold storages in Bangladesh with a capacity of about 5.3 million tons that can store only $53 \%$ of produced potatoes including seeds (BBS, 2018).

Potato can either be cooked and consumed directly or processed to a variety of commercial products (Lisinski and Leszczynski, 1989). As potato has a wide consumption so it is required to store for long and short time when the potato is not available. The chemical traits of potato tubers can change within storage time as it can respire during storage. As a result, dry matter breaks down and weight loss is occurred (Gottschalk and Ezhekiel, 2006). Processing quality of potato tubers is determined by high dry matter and low reducing sugar and phenol contents (Kadam et al., 1991). High dry matter content increases chip yield, crispy-consistency and reduces oil absorption during cooking (Rommens et al., 2010). For better chipping $1.5 \mathrm{mg} / \mathrm{g}$ sucrose, 20 to $27 \%$ dry matter content and 1.07 to 1.10 specific gravity should be maintained in processing potato (Work et al., 1981). Kabira and Berga (2003) reported that potato tubers had 20-24 \% DM content indicating that they are ideal for processing chips.

Reducing sugars accumulation in potato tubers during low temperature storage is of prime industrial concern due to its participation as substrate in Millard reaction at elevated temperature. The high level of reducing sugars gives rise to commercially unacceptable brown crisp color (Blenkinsop et al., 2002). Low temperature $\left(4^{\circ} \mathrm{C}\right)$ storage helps to reduce problem of sprout growth and losses due to diseases and rotting. However, the resultant low temperature sweetening of the tubers reduces the chip quality within a short time period (Isherwood, 1973). Wiltshire and Cobb (1996) reported that higher temperature increase metabolism, respiration and physiological aging of potato tubers, resulting in the observed earlier sprouting and starch breakdown, ultimately lower DM content. Optimum reducing sugar content for processing potatoes is $1.0 \mathrm{mg} / \mathrm{g}$ and it should not exceed $3.30 \mathrm{mg} / \mathrm{g}$ (Davies and Viola, 1992).

To keep the dry matter content at desirable level low temperature is prerequisite (Work et al., 1981). The evaporative cooled storage structure has proved to be useful for short term and on-farm storage of fruits and vegetables in hot and dry regions (Jha and Chopra, 2006). The high cost involved in developing cold storage or controlled atmosphere storage is a pressing problem in several developing countries including Bangladesh. But evaporative cool chamber is able to maintain temperature at $10-15^{\circ} \mathrm{C}$ below ambient as well as at a relative humidity of $90 \%$ depending on season (Basediya et al., 2013). Evaporative cooling is an environment friendly air conditioning system that operates using induced process of heat and mass transfer where water and air are working fluids. It is very cheap and fulfills all the requirements to the small farmers in rural area (Dadhich et al., 2008).

Due to warm weather, it is a great challenge to maintain the processing quality of the stored potatoes in Bangladesh. Different types of pits, 
earthen house, bamboo house and cold storage have been using to store potatoes in the subcontinent including Bangladesh. Bangladesh Agricultural Research Institute (BARI) and other research partners prescribed an ambient type potato storage (bamboo house) and a coolbot for storing potatoes after harvest (CIP, 2013 and BAMD, 2018). But none of the techniques has been proved to be efficient to maintain processing quality of potato varieties during the storage period of this country.

Considering the above facts, the aim of this experiment was to find out a suitable storage condition to maintain the processing quality of potatoes at a desirable level by means of economical friendly method.

\section{Materials and Methods}

The research was carried out in the Department of Crop Botany, Bangabandhu Sheikh Mujibur Rahman Agricultural University (BSMRAU), Salna, Gazipur. Seed potatoes of three processing varieties viz. Asterix (BARI Alu-25), Courage (BARI Alu-29) and Lady Rosseta (BARI Alu-28) were collected from Bangladesh Agricultural Development Corporation (BADC) and Tuber Crops Research Center (TCRC) of Bangladesh Agricultural Research Institute (BARI) and then cultivated at the field laboratory of the Department of Crop Botany (Block 14) by following standard cultivation and management practices for potato prescribed by BADC and TCRC, BARI. After harvesting, potatoes were subjected to curing for 10 days and sent to the different storage conditions. Potato tubers were stored in 3 conditions: a low cost earthen chamber with evaporative cooler (EC), bamboo chamber (BC) [as recommended by TCRC, BARI] and refrigerator $(\mathrm{RF})$.

\section{Design and fabrication of storage chambers}

$\mathrm{BC}$ was made by bamboo and bamboo sheets and its size was $5 \mathrm{ft} \times 4 \mathrm{ft} \times 3 \mathrm{ft}(\mathrm{L} \times \mathrm{W} \times \mathrm{H})$. The size of $\mathrm{EC}$ was $5 \mathrm{ft} \times 4 \mathrm{ft} \times 3 \mathrm{ft}(\mathrm{L} \times \mathrm{W} \times \mathrm{H})$ and it was made by clay soil. Three holes were made on earthen wall among those two for ventilation purpose and one was used for the entrance of airflow with vapor by evaporative cooler (Model- WRA-S99, Walton, Bangladesh). An electricity power supply was connected to the evaporative cooler as well as narrow tube was jointed to the cooler for continuous water supply. A giant refrigerator (Model- ER202F, General Electronics. Japan) was used as the refrigerated storage. A thermo-hygrometer was kept inside each chamber as well as in the external environment.

\section{Data collection}

Data were collected at the day before storage and then 1-month interval basis up to 3 months on dry matter (\%), weight loss (\%), shrinkage (\%), glucose, fructose, reducing sugar, sucrose, and total soluble sugar and starch contents. After the termination of 90 days storage, sensory evaluation of chips prepared from stored potatoes was conducted.

Dry matter content (\%), weight loss (\%) and shrinkage (\%) were determined as the procedures described by Abano et al. (2011). Energy content of potato tubers was calculated according to Bradbury (1986) by using the equation $\mathrm{E}=-17.38 \mathrm{M}+1699$, where, $\mathrm{E}=$ Energy in kJ per unit weight (100 gm) and $\mathrm{M}$ $=$ Moisture content $(\%)$. Cooling efficiency was determined according to Abano et al. (2011) using the maximum and minimum temperatures of external environment and the maximum temperature inside storage. 


\section{Extraction and determination of soluble sugars}

Sugar content of potato flesh was extracted by following the procedure of Xue (1985) with slight modification. Briefly, $0.5 \mathrm{~g}$ of fresh potato flesh was extracted thrice with $5 \mathrm{ml}$ of $80 \%(\mathrm{v} / \mathrm{v})$ ethanol at $80^{\circ} \mathrm{C}$ for $30 \mathrm{~min}$ and the extracts were centrifuged at $5000 \mathrm{rpm}$ for 10 min with a refrigerated centrifuge (ModelBCBHR-201, Bio LAB, Canada). The supernatants were combined in a $50 \mathrm{ml}$ beaker and placed in a water bath at $80-85^{\circ} \mathrm{C}$ until the volume is reduced to about $1 \mathrm{ml}$. The sugar extract was transferred to a $10 \mathrm{ml}$ volumetric flask by 3-4 wash with distilled water and used for assaying total soluble sugars, reducing sugar, sucrose, glucose and fructose contents.

Glucose content was estimated spectrophotometrically by glucose enzymatic assay kit (Linear Chemical, Spain) following the procedure attached with the kit pack. Fructose and sucrose content of potato flesh was measured by the anthrone colorimetric method following the procedure of Kang et al. (2009). Reducing sugar content was measured by DNS colorimetric method following the procedure of Miller (1959) with some modifications. Total soluble sugar was calculated by the summation of glucose, fructose and sucrose contents as done by the Adu-Kwarteng et al. (2014). A series of standard solution was made for glucose, fructose, sucrose and reducing sugar to prepare standard curves for the quantification of the sugar components.

\section{Extraction and determination of starch}

Starch content was extracted following the procedure described by Kang et al. (2009). Then $1 \mathrm{ml}$ of aliquot was mixed with $1 \mathrm{ml}$ of distilled water and $5 \mathrm{ml}$ of anthrone reagent, and boiled for $15 \mathrm{~min}$. After cooling for 10 min in the dark, the absorbance was read at $620 \mathrm{~nm}$ using spectrophotometer. A series of standard solution was made using starch for the preparation of standard curve.

\section{Preparation of chips and sensory evaluation}

After the termination of 90 days' storage, potato chips were produced according to Kita et al. (2014) with slight modification. After washing potatoes were cut into slices of $2 \pm$ $0.1 \mathrm{~mm}$ thickness with a potato slicer, washed in cold saline water $(\mathrm{NaCl} @$ of 20 g/L) and superficially dried by paper towels. The chips were deep fried about $3 \mathrm{~min}$ in refined rice bran oil heated to $180^{\circ} \mathrm{C}$. After discharging of the oil and cooling, chips were taken for sensory evaluation. Sensory evaluation was performed by an untrained panel $(n=10,21$ 30 yrs, 4 males and 6 females) who were the regular consumer of potato chips. Samples were randomly coded before being served to the panel. Five sensory quality parameters (color, texture, taste, crispiness and the overall acceptability) were individually evaluated based on a 9-point hedonic scale (1: dislike extremely and 9: like extremely) as described by Meilgaard et al. (2007).

\section{Statistical analysis}

Statistical analysis was performed using Statistix 10 data analysis software. Monthly data collected throughout the storage duration were averaged and subjected to two-way analysis of variance for mean comparison, and significant differences were calculated according to Tukey's HSD test. Data were reported as mean \pm standard error (SE). Differences at $\mathrm{p} \leq 0.05$ were considered to be statistically significant. Periodical data were presented in the graphs as the mean $\pm \mathrm{SE}$ of 3 
varieties with 3 replications for each storage conditions.

\section{Results and Discussion}

Storage temperature and relative humidity Daily mean temperature $\left({ }^{\circ} \mathrm{C}\right)$ and mean relative humidity (RH) during the storage period (April 2016 to July 2016) were presented in Fig. 1. The temperature in the bamboo chamber (BC) ranged from $27.0-32.0^{\circ} \mathrm{C}$ (mean $29.99^{\circ} \mathrm{C}$ ) during the storage period which was $3.0-6.0^{\circ} \mathrm{C}$ lower than the external environmental temperature $\left(30.5-35.0^{\circ} \mathrm{C}\right)$. Temperature inside the earthen chamber (EC) was ranged from $25-30^{\circ} \mathrm{C}$ (mean $27.93^{\circ} \mathrm{C}$ ) which was $5.5-10.0^{\circ} \mathrm{C}$ lower than the external temperature during the period of storage. The moist air by evaporative cooler reduces the inside temperature of the EC. On the

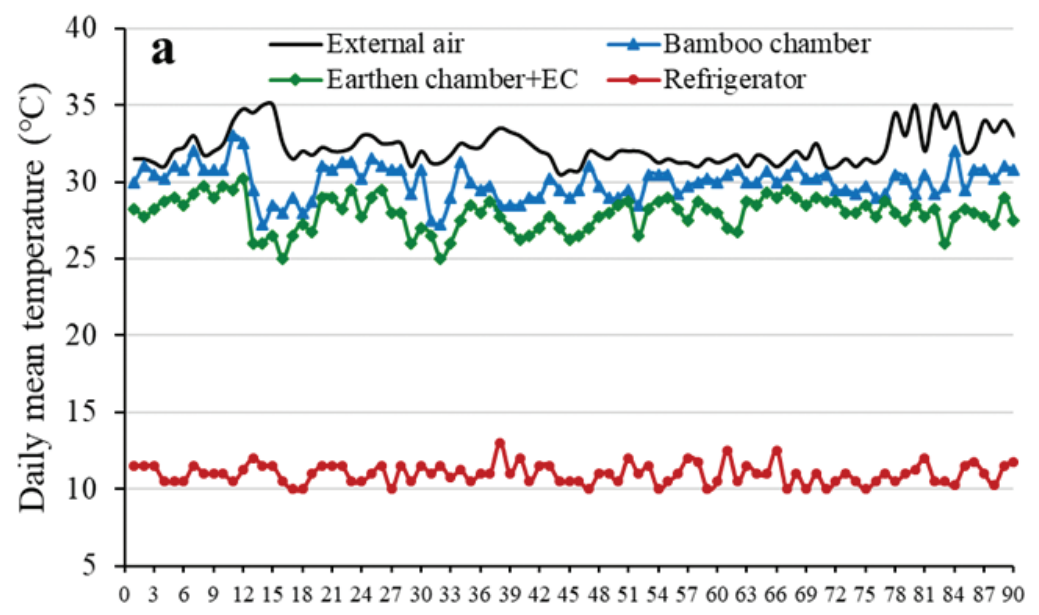

Days of storage

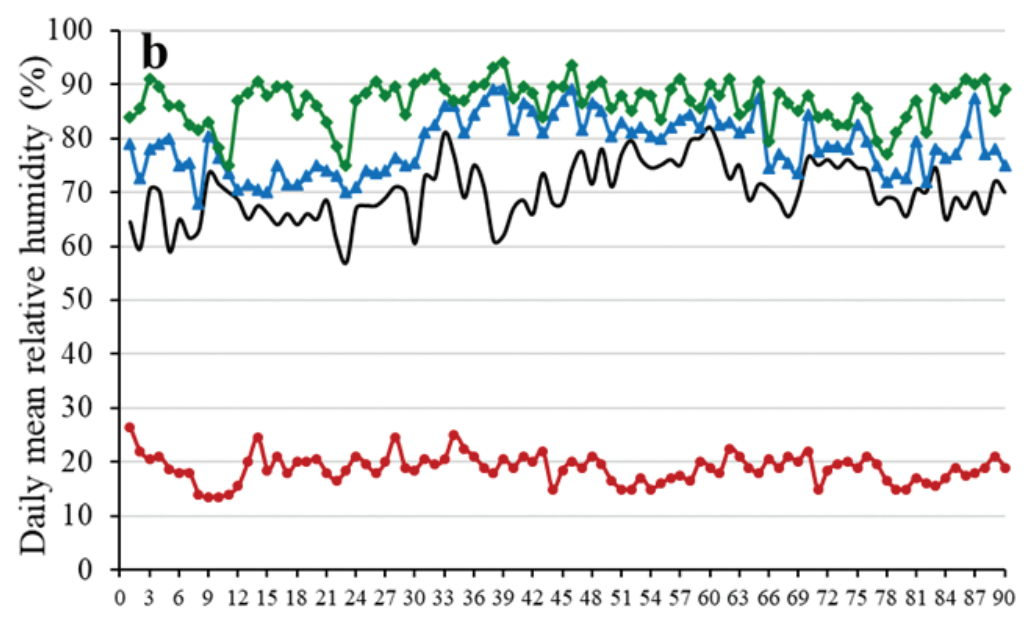

Days of storage

Fig. 1. Daily mean temperature (a) and daily mean relative humidity (b) of the external environment, bamboo chamber, earthen chamber and refrigerator of the entire storage duration. 
other hand, temperature in the refrigerator (RF) ranged from $10-12^{\circ} \mathrm{C}$ (mean $10.99^{\circ} \mathrm{C}$ ) which was much lower than external air, BC and EC temperature. The relative humidity (RH) of the external environment ranged from 57.0-82.0\% (mean 70.1\%) was lower than the inside humidity of EC which ranged from $75.0-94.0 \%$ (mean $86.7 \%$ ). The RH of EC was 12.0-16.0\% higher than the external humidity as moist air was pumped inside the EC by evaporative cooler. The $\mathrm{RH}$ of $\mathrm{BC}$ was $68.0-89.0 \%$ (mean $78.8 \%$ ) and that was 7.0-11.0\% lower than the external humidity. Besides, in the RF, the relative humidity ranged from $13.5-26.5 \%$ (mean 18.8\%) that was much lower compared to other two storage conditions. The cooling efficiency of the $\mathrm{BC}, \mathrm{EC}$ and $\mathrm{RF}$ was 44.4, 105.6 and $488.9 \%$, respectively (Fig 2 ).

The ANOVA showed that the main effects of the varieties were significant for all the processing qualities, but the main effect of storage conditions were significant except dry matter content (DM) and total soluble sugars (TSS) (Table 1). Two-way interaction between the varieties and storage conditions was insignificant for all processing qualities apart from fructose content.

\section{Dry matter content (\%)}

The highest mean DM content was found in the RF (22.44\%) compared to BC (21.84\%) and $\mathrm{EC}(22.13 \%)$ but the differences between them were insignificant (Table 2). Among the varieties, DM content of Asterix was significantly lower than those of Courage and Lady Rosetta in all storage conditions. DM content of potato varieties was decreased with the increased storage duration in all three storage condition (Fig 3a). But the degree of declining DM content was varied within the storage duration as well as among the potato varieties. Results revealed that the DM content was decreased slowly up to 30 days but at the later stages with the progression of storage duration, the DM content declined rapidly in all three potato varieties. This decline in DM content was happened probably due to the loss of moisture from the tubers and maintenance respiration during storage (Addisu et al., 2014). The decrease in DM content with storage time in the present study corroborate the results of de Freitas et al. (2012) and Addisu et al. (2014) who reported a significant decreasing trend in the specific gravity and DM content of the potato tubers stored in different storage conditions. The decrease in the DM with

Table 1. Mean squares of variance and their effect on dry matter content (DM), weight loss (WL), shrinkage (SR), energy content (ENG), reducing sugar (RS), sucrose (SUC), glucose (GLU), fructose (FRU), total soluble sugar (TSS) and starch content (SC) of potato tubers stored in different storage conditions

\begin{tabular}{lccccccccccc}
\hline \multirow{2}{*}{$\begin{array}{l}\text { Source of } \\
\text { variation }\end{array}$} & DF & \multicolumn{10}{c}{ Mean Squares } \\
\cline { 2 - 11 } & & DM & WL & SR & ENG & RS & SUC & GLU & FRU & TSS & SC \\
\hline Variety $(\mathrm{V})$ & 2 & $42.77^{* *}$ & $1.09^{* *}$ & $4.75^{* *}$ & $0.64^{* *}$ & $0.97^{* *}$ & $0.73^{* *}$ & $0.23^{* *}$ & $6.07^{* *}$ & $103.99^{* *}$ & $14.45^{* *}$ \\
Storage(S) & 2 & 0.81 & $2.76^{* *}$ & $3.57^{*}$ & $0.27^{* *}$ & $0.39^{* *}$ & $0.35^{* *}$ & $0.28^{* *}$ & $2.23^{* *}$ & 3.33 & $6.35^{* *}$ \\
V $\times \mathrm{S}$ & 4 & 0.09 & 0.04 & 0.27 & 0.014 & 0.01 & 0.05 & 9.52 & $0.26^{*}$ & 0.83 & 0.53 \\
Error & 16 & 0.56 & 0.16 & 0.90 & 0.018 & 0.033 & 0.02 & 18.50 & 0.06 & 1.34 & 0.09 \\
\hline
\end{tabular}

*indicates significant at $p \leq 0.05 ;{ }^{* *}$ indicates significant at $p \leq 0.01$ 


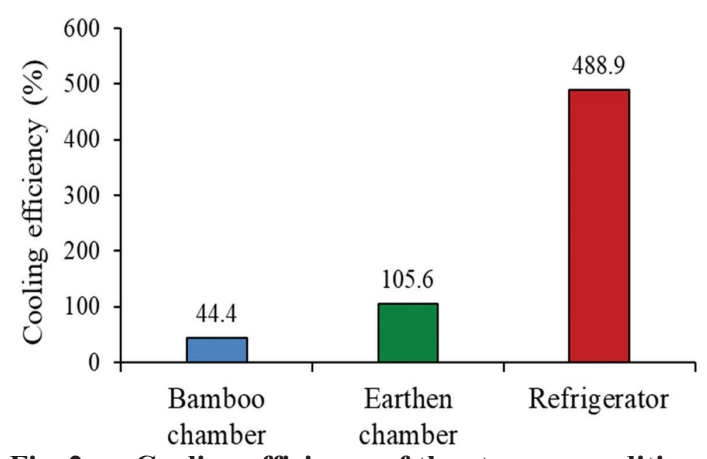

Fig. 2. Cooling efficiency of the storage conditions used in this study.

storage time can be attributed to the gradual respiratory biochemical starch breakdown to sugars that is used up to maintain life of the tuber with concurrent production of carbon dioxide and water vapor (Senkumba et al., 2017; Addisu et al., 2014).

Results of the study clearly showed that, the mean DM content was higher in the RF compared to $\mathrm{EC}$ and $\mathrm{BC}$ in all sampling days (Fig 3a). This might be due to the low temperature in RF compared to other two conditions that prevented evaporation of moisture from tissues and less respiratory loss. Result of the present study agreed with the findings of de Freitas et al. (2012) who reported that lower storage temperature (4 and $\left.8^{\circ} \mathrm{C}\right)$ tended to be more effective in maintaining DM content. Potatoes retained comparatively low DM content in $\mathrm{BC}$ and $\mathrm{EC}$ was due to early sprouting \& higher carbohydrate breakdown in comparatively high temperature in these storage then refrigerator. Wiltshire and Cobb (1996) reported that higher temperature increase metabolism, respiration and physiological aging of potato tubers, resulting in the observed earlier sprouting and starch breakdown, ultimately lower DM content. Kabira and Berga (2003) reported that potato tubers had $20-24 \%$ DM content indicating that they are ideal for processing chips. The result of the current study clearly showed that EC and RF could be able to retain desirable DM content (above 20\%) for processing chips up to the 90 days than that of BC.

\section{Tuber weight loss}

Mean percent weight loss (WL) of potato tubers in the $\mathrm{BC}(3.96 \%)$ was significantly higher than EC (3.40\%) and RF (2.85\%) (Table 2). Though the varieties Courage and Lady Rosetta were able to maintain lower WL than that of Asterix but the varietal differences were insignificant for all storage conditions. WL of potato tubers increased with the advancement of storage period and at the later stage of storage, there was a tremendous increase of WL in all storage conditions (Fig 3b). The highest WL was found in BC in all sampling dates as the high temperature enhances the respiration and evaporation of water from potato. The gradual increase in WL was due to maintenance respiration which converts the valuable starch in presence of oxygen to carbon dioxide, water and heat (Tester et al., 2005). Ezekiel et al. (2007) reported that the gradual WL increased due to respiration and evaporation, sprouting and sprout growth. Besides, high weight loss at room temperature is due to prevailing high temperature and low relative humidity which are reported to increase respiration rate (Burton, 1966), evaporation (Schippers, 1971) and sprouting (Burton, 1973). In this study, WL was less in EC compared to BC in all three potato varieties. Prevalence of high humidity and low vapor pressure deficit in evaporative cooled storage proved effective in reducing the WL as compared to room temperature 
storage as already reported by Burton (1966). RF showed minimum WL compared to other storage conditions (Fig 3b). Similar results were reported by Perumal et al. (1980), i.e., maximum $\mathrm{WL}$ of potato tuber at room temperature and minimum $\mathrm{WL}$ at refrigerated condition during the storage period.

\section{Shrinkage}

Mean percent shrinkage (SR) of potato tubers in $\mathrm{BC}(4.91 \%)$ was markedly higher than EC (3.44\%) and RF (2.93\%) (Table 2).
Varietal differences within and among the storage conditions were not significant. SR of potato tubers was increased with the storage duration in all storage conditions (Fig 3c). But the degree of increment varied within the storage conditions, storage duration and potato varieties. The SR was higher in $\mathrm{BC}$ than that of $\mathrm{EC}$ and $\mathrm{RF}$ for all potato varieties, because high temperature (Sonnewald and Sonnewald, 2014) and low humidity (Abano et al., 2011) were responsible for the loss of water from potato tuber causes higher SR in
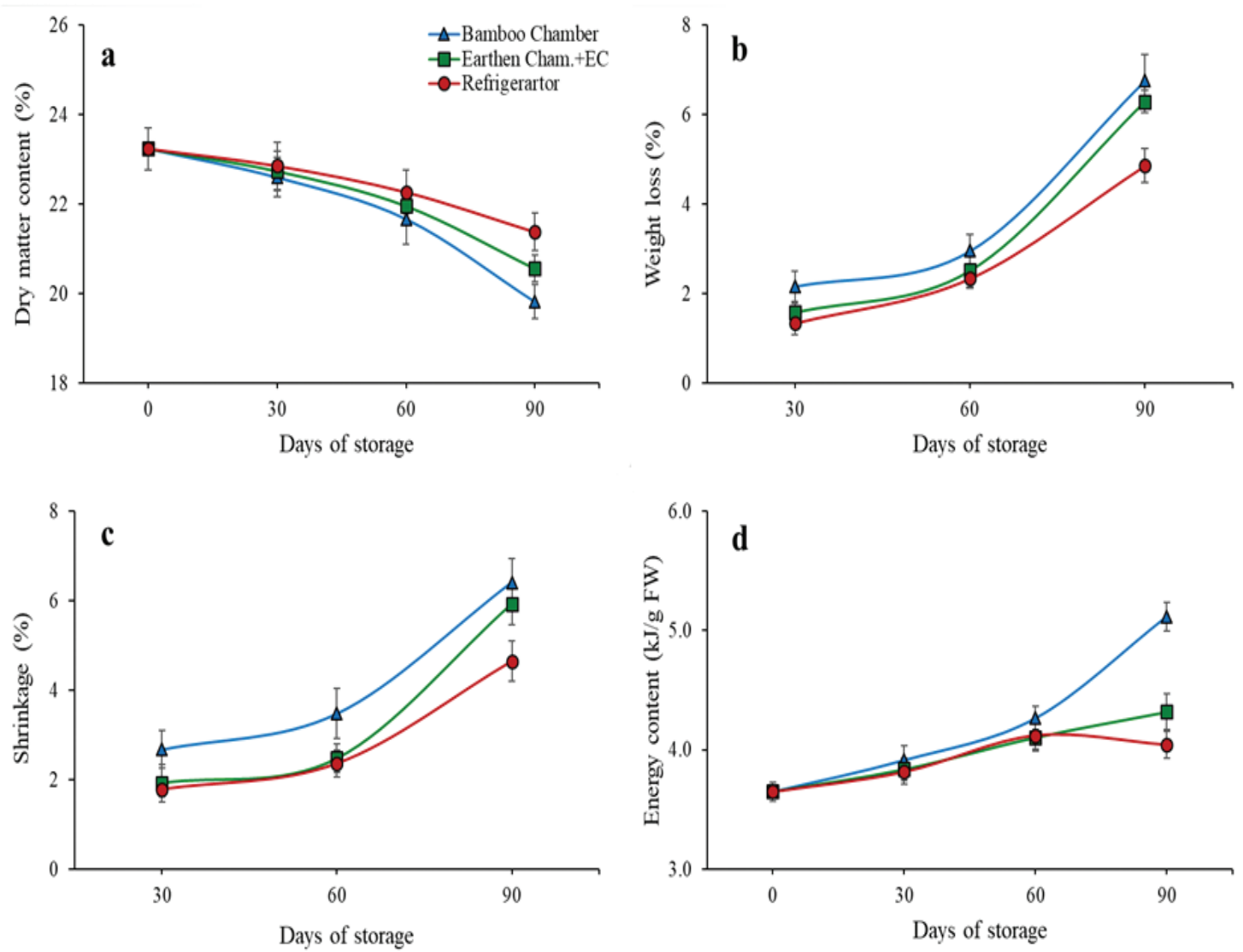

Fig. 3. Dry matter content (a) weight loss\% (b) shrinkage (c) and energy content (d) of three processing potato varieties in three storage conditions recorded at 30-day interval up to 90 days of storage. Means were calculated from three varieties with three replicates. Vertical bars represent the \pm SE values for the data point. 
the BC. In the EC, the SR was low $(5.92 \%$ at 90 days) compared to $\mathrm{BC}$ and this might be due to comparatively low temperature with high relative humidity created by evaporative cooler inside the EC (Abano et al., 2011). The potato tubers of RF showed the minimum SR $(4.65 \%$ at 90 days) due to the very low temperature.

\section{Energy content}

Potato tubers stored in $\mathrm{BC}$ had significantly higher mean energy content $(4.24 \mathrm{~kJ} / \mathrm{g})$ than that of EC $(3.97 \mathrm{~kJ} / \mathrm{g})$ and $\mathrm{RF}(3.91$ $\mathrm{kJ} / \mathrm{g}$ ) (Table 2). Lady Rosetta maintained significantly higher mean energy content than that of Asterix and Courage in all storage conditions. Energy content of the potato tubers increased with the storage duration in all storage conditions (Fig. 3d). Results revealed that with the advancement of the storage duration, energy content of the potato tubers increased up to the end of the storage. Similar results were found by Abano et al. (2011) and Zhitian et al. (2002). The highest energy content was found in potato tubers of $\mathrm{BC}(4.68 \mathrm{~kJ} / \mathrm{g}$ at 90 days) and the lowest was found in the RF. Higher energy content apparently indicates the lower starch content available in the tubers.

\section{Reducing sugar content}

Significantly higher mean reducing sugar content (RS) was found in the potato tubers

Table 2. Summary statistics showing the values and means of different physico-chemical qualities of three processing potato varieties stored in different storage conditions

\begin{tabular}{|c|c|c|c|c|c|c|c|c|c|c|c|}
\hline $\begin{array}{l}\text { Storage } \\
\text { condition }\end{array}$ & Variety & DM & WL & SR & ENG & RS & SUC & GLU & FRU & TSS & $\mathrm{SC}$ \\
\hline \multirow{4}{*}{$\begin{array}{l}\text { Bamboo } \\
\text { chamber }\end{array}$} & Asterix & $19.10^{\mathrm{b}}$ & $4.29^{\mathrm{a}}$ & $4.66^{\mathrm{a}}$ & $3.83^{\mathrm{ce}}$ & $2.80^{\mathrm{ab}}$ & $2.49^{\mathrm{ab}}$ & $0.41^{\mathrm{b}}$ & $3.90^{\mathrm{a}}$ & $6.82^{\mathrm{b}}$ & $94.86^{c}$ \\
\hline & Courage & $23.07^{\mathrm{a}}$ & $3.82^{\mathrm{ab}}$ & $3.90^{\mathrm{a}}$ & $4.41^{\mathrm{ab}}$ & $2.22^{\mathrm{c}}$ & $2.22^{\mathrm{b}-\mathrm{d}}$ & $0.16^{\mathrm{e}}$ & $2.33^{\mathrm{bc}}$ & $4.72^{\mathrm{c}}$ & $99.68^{\mathrm{ab}}$ \\
\hline & Lady Rosetta & $23.33^{\mathrm{a}}$ & $3.75^{\mathrm{ab}}$ & $3.99^{\mathrm{a}}$ & $4.46^{\mathrm{a}}$ & $2.20^{\mathrm{c}}$ & $2.21^{\mathrm{bc}}$ & $0.18^{\mathrm{de}}$ & $2.10^{\mathrm{bc}}$ & $4.50^{\text {cd }}$ & $101.52^{\mathrm{a}}$ \\
\hline & Mean & $21.84^{\mathrm{A}}$ & $3.96^{\mathrm{A}}$ & $4.19^{\mathrm{A}}$ & $4.24^{\mathrm{A}}$ & $2.41^{\mathrm{B}}$ & $2.31^{\mathrm{A}}$ & $0.27^{\mathrm{B}}$ & $2.78^{\mathrm{A}}$ & $5.35^{\mathrm{B}}$ & $98.69^{\mathrm{A}}$ \\
\hline \multirow{4}{*}{$\begin{array}{l}\text { Earthen } \\
\text { chamber }\end{array}$} & Asterix & $19.65^{b}$ & $3.74^{\mathrm{ab}}$ & $4.53^{\mathrm{a}}$ & $3.71^{\mathrm{de}}$ & $2.59^{\mathrm{bc}}$ & $2.40^{\mathrm{b}}$ & $0.24^{\mathrm{d}}$ & $2.51^{\mathrm{b}}$ & $5.16^{\mathrm{c}}$ & $96.72^{\mathrm{c}}$ \\
\hline & Courage & $23.25^{\mathrm{a}}$ & $3.15^{\mathrm{a}-\mathrm{c}}$ & $2.76^{\mathrm{a}}$ & $4.07^{\mathrm{a}-\mathrm{d}}$ & $2.13^{\mathrm{c}}$ & $1.85^{\mathrm{d}}$ & $0.12^{\mathrm{e}}$ & $1.74^{\mathrm{c}}$ & $3.72^{\mathrm{d}}$ & $100.11^{\mathrm{ab}}$ \\
\hline & Lady Rosetta & $23.49^{\mathrm{a}}$ & $3.30^{a-c}$ & $3.03^{\mathrm{a}}$ & $4.14^{\mathrm{a}-\mathrm{c}}$ & $2.12^{\mathrm{c}}$ & $1.93^{\mathrm{cd}}$ & $0.12^{\mathrm{e}}$ & $1.62^{\mathrm{c}}$ & $3.68^{\mathrm{d}}$ & $102.86^{\mathrm{a}}$ \\
\hline & Mean & $22.13^{\mathrm{A}}$ & $3.40^{\mathrm{B}}$ & $3.44^{\mathrm{AB}}$ & $3.97^{\mathrm{B}}$ & $2.28^{\mathrm{B}}$ & $2.07^{\mathrm{B}}$ & $0.17^{\mathrm{c}}$ & $1.96^{\mathrm{B}}$ & $4.20^{\mathrm{c}}$ & $99.91^{\mathrm{A}}$ \\
\hline \multirow{5}{*}{ Refrigerator } & Asterix & $20.12^{b}$ & $3.37^{\mathrm{ac}}$ & $3.88^{\mathrm{a}}$ & $3.65^{\mathrm{e}}$ & $3.13^{\mathrm{a}}$ & $2.91^{\mathrm{a}}$ & $0.82^{\mathrm{a}}$ & $4.01^{\mathrm{a}}$ & $7.76^{\mathrm{a}}$ & $94.99^{\mathrm{c}}$ \\
\hline & Courage & $23.45^{\mathrm{a}}$ & $2.48^{\mathrm{c}}$ & $2.55^{\mathrm{a}}$ & $4.02^{\mathrm{bee}}$ & $2.50^{\mathrm{bc}}$ & $2.33^{\mathrm{bc}}$ & $0.33^{c}$ & $2.34^{\mathrm{bc}}$ & $5.01^{\mathrm{c}}$ & $100.4^{a}$ \\
\hline & Lady Rosetta & $23.74^{a}$ & $2.69^{\mathrm{bc}}$ & $2.35^{\mathrm{a}}$ & $4.06^{-a-d}$ & $2.44^{\mathrm{bc}}$ & $2.13^{\mathrm{b}-\mathrm{d}}$ & $0.36^{\mathrm{bc}}$ & $2.21^{\mathrm{bc}}$ & $4.70^{c}$ & $102.16^{\mathrm{a}}$ \\
\hline & Mean & $22.44^{\mathrm{A}}$ & $2.85^{\mathrm{C}}$ & $2.93^{\mathrm{B}}$ & $3.91^{\mathrm{B}}$ & $2.69^{\mathrm{A}}$ & $2.46^{\mathrm{A}}$ & $0.51^{\mathrm{A}}$ & $2.86^{\mathrm{A}}$ & $5.83^{\mathrm{A}}$ & $99.19^{\mathrm{A}}$ \\
\hline & CV (\%) & 3.41 & 11.95 & 13.04 & 3.42 & 7.39 & 6.79 & 7.50 & 10.17 & 5.95 & 3.17 \\
\hline
\end{tabular}

Values and means in a column followed by same lowercase and uppercase letter(s), respectively are not statistically different at $p<0.05$ by Tukey's HSD test. Values are the average of 4 sampling dates with 3 replicates.

$\mathrm{DM}=$ dry matter content $(\%), \mathrm{WL}=$ weight loss $(\%), \mathrm{SR}=$ shrinkage $(\%), \mathrm{ENG}=$ energy content $(\mathrm{kJ} / \mathrm{g} \mathrm{FW})$, $\mathrm{RS}=$ reducing sugar $(\mathrm{mg} / \mathrm{g} \mathrm{FW}), \mathrm{SUC}=$ sucrose $(\mathrm{mg} / \mathrm{g} \mathrm{FW}), \mathrm{GLU}=$ glucose $(\mathrm{mg} / \mathrm{g} \mathrm{FW}), \mathrm{FRU}=$ fructose $(\mathrm{mg} / \mathrm{g} \mathrm{FW}), \mathrm{TSS}=$ total soluble sugar $(\mathrm{mg} / \mathrm{g} \mathrm{FW})$ and $\mathrm{SC}=$ starch content $(\mathrm{mg} / \mathrm{g} \mathrm{FW})$. 
stored in RF $(2.69 \mathrm{mg} / \mathrm{g} \mathrm{FW})$ than that of EC $(2.28 \mathrm{mg} / \mathrm{g} \mathrm{FW})$ and $\mathrm{BC}(2.41 \mathrm{mg} / \mathrm{g} \mathrm{FW})$, but there was no statistically significant difference between mean RS content of EC and BC (Table 2). Courage and Lady Rosetta showed significantly lower RS content than Asterix both in $\mathrm{BC}$ and $\mathrm{RF}$, but the difference among these varieties in the $\mathrm{EC}$ was not significant. RS content of potato tubers increased progressively with the increased storage duration in all storage conditions (Fig 4a). Similar increase in the RS content of ambient stored potatoes was reported by Pandey et al. (2017). The increase of RS content was rapid in RF compared to $\mathrm{BC}$ and EC. At the 90 days of storage period, potato varieties retained $3.71 \mathrm{mg} / \mathrm{g} R S$ content in the RF while that was 2.89 and $3.20 \mathrm{mg} / \mathrm{g}$ in EC and $\mathrm{BC}$, respectively (Fig 4a). It indicated that very low temperature enhanced the increase of RS in potatoes and it might be due to the increased invertase enzyme activity at low temperature condition. Huang et al. (1999) found the similar result in low temperature storage condition. RS content of potatoes was remarkably low in tubers stored at the room temperature and under evaporative cooled storage as compared to the tubers stored in refrigerated storage (Mehta and Kaul, 1988). Reducing sugars such as fructose and glucose in reaction with $\alpha$-amino groups form dark color and give a bitter taste to fried potatoes (Davies and Viola, 1992). Sweeter taste and soft texture in a fried potato product probably due to the low content of starch and increased content of RS (Adams, 2004). Optimum content of RS for processing potatoes is 1.00 $\mathrm{mg} / \mathrm{g}$ and it should not exceed $3.30 \mathrm{mg} / \mathrm{g}$ (Davies and Viola, 1992). In our study, potato tubers retained RS content below $3.30 \mathrm{mg} / \mathrm{g}$ up to 90 days in EC $(2.89 \mathrm{mg} / \mathrm{g})$ and $\mathrm{BC}(3.20$ $\mathrm{mg} / \mathrm{g}$ ), but RF $(3.71 \mathrm{mg} / \mathrm{g}$ ) failed to do so. Therefore, the EC was considerably suitable for storing potatoes to maintain desirable RS content for processing in the storage.

\section{Sucrose content}

Significantly lower mean sucrose content (SUC) was found in the potato tubers stored in $\mathrm{EC}(2.07 \mathrm{mg} / \mathrm{g} \mathrm{FW})$ than that of RF $(2.46 \mathrm{mg} / \mathrm{g}$ $\mathrm{FW})$ and $\mathrm{BC}(2.31 \mathrm{mg} / \mathrm{g} \mathrm{FW})$, but there was no statistically significant difference between mean SUC content of BC and RF (Table 2). Variety Asterix showed significantly higher SUC content than that of Courage and Lady Rosetta both in EC and RF, but the difference among these varieties in BC was not significant. SUC content of potato tubers was increasing with the storage period in every storage condition (Fig 4b). The increase in SUC content was rapid in RF compared to $\mathrm{EC}$ and $\mathrm{BC}$. Potato tubers retained highest SUC content $(3.60 \mathrm{mg} / \mathrm{g} \mathrm{FW})$ at the last day of storage period in RF than that of EC (2.68 $\mathrm{mg} / \mathrm{g} \mathrm{FW}$ ) and BC (3.21 mg/g FW) (Fig 4b). It might be due to the breakdown of starch molecule and its conversion into sucrose in the low temperature condition (Edward et al. 2002). Comparatively lower SUC content in the EC was due to the intermediate storage temperatures prevent accumulation sucrose, glucose and fructose contents in potato (Sowokinos, 1990). But, the potato tubers of BC contained more SUC content than EC because high temperature was attributed to the increase in SUC concentration in potato tubers (Timm et al., 1968). Potato tubers with high SUC level tend to accumulate more RS and are therefore not suitable for processing; and potatoes with SUC content greater than 
$1.5 \mathrm{mg} / \mathrm{g} \mathrm{FW}$ is good for chips (Sowokinos et al., 1987) and it can be maximized up to 2.80 $\mathrm{mg} / \mathrm{g}$ FW (Work et al., 1981) processing. The potato of the EC showed below 2.80 $\mathrm{mg} / \mathrm{g}$ FW SUC up to the 90 days. On the contrary, the potato tubers of RF and BC lost processing quality after 60 days of storage period as the SUC content of potatoes of these two conditions were 3.60 and 3.21 $\mathrm{mg} / \mathrm{g} \mathrm{FW}$, respectively. So, potatoes retained processing quality for long time in the EC than RF and BC.
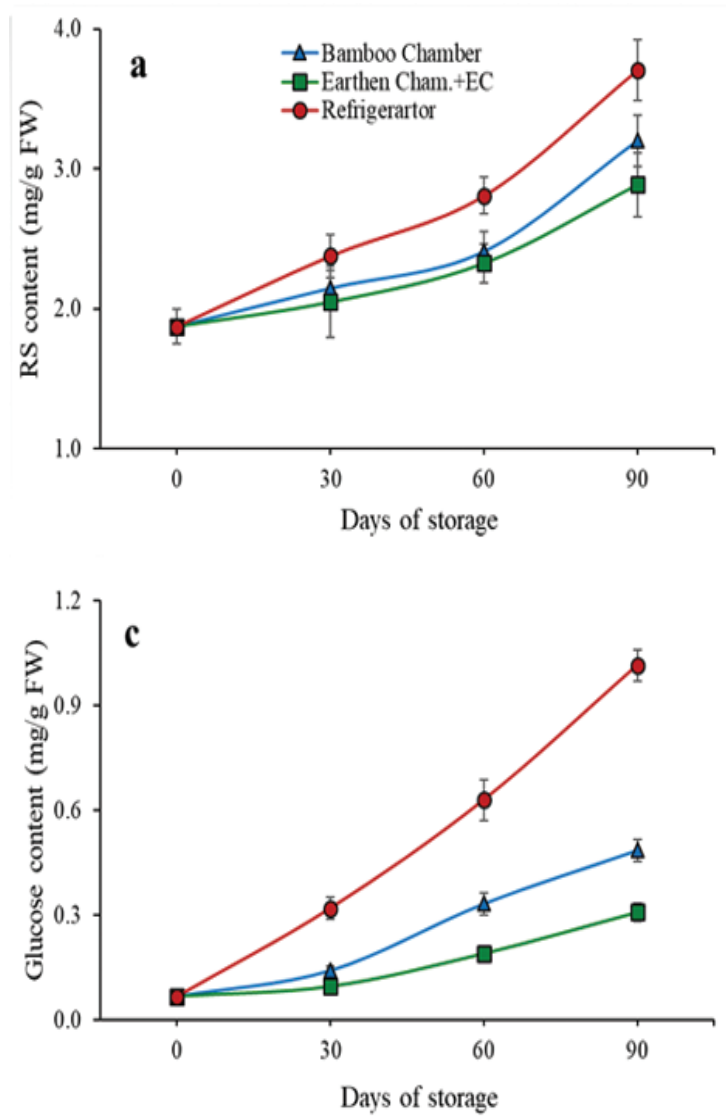

\section{Glucose content}

Potato tubers stored in the EC retained significantly lower mean glucose (GLU) content $(0.17 \mathrm{mg} / \mathrm{g} \mathrm{FW})$ than that of $\mathrm{BC}(0.27$ $\mathrm{mg} / \mathrm{g} \mathrm{FW}$ ) and RF (0.51 mg/g FW) (Table 2). Among the potato varieties, Asterix showed significantly higher GLU content than that of Courage and Lady Rosetta in all three storage conditions. GLU content of potato tubers increased with the advancement of storage duration in all storage conditions (Fig $4 c)$. The increase of GLU content was rapid
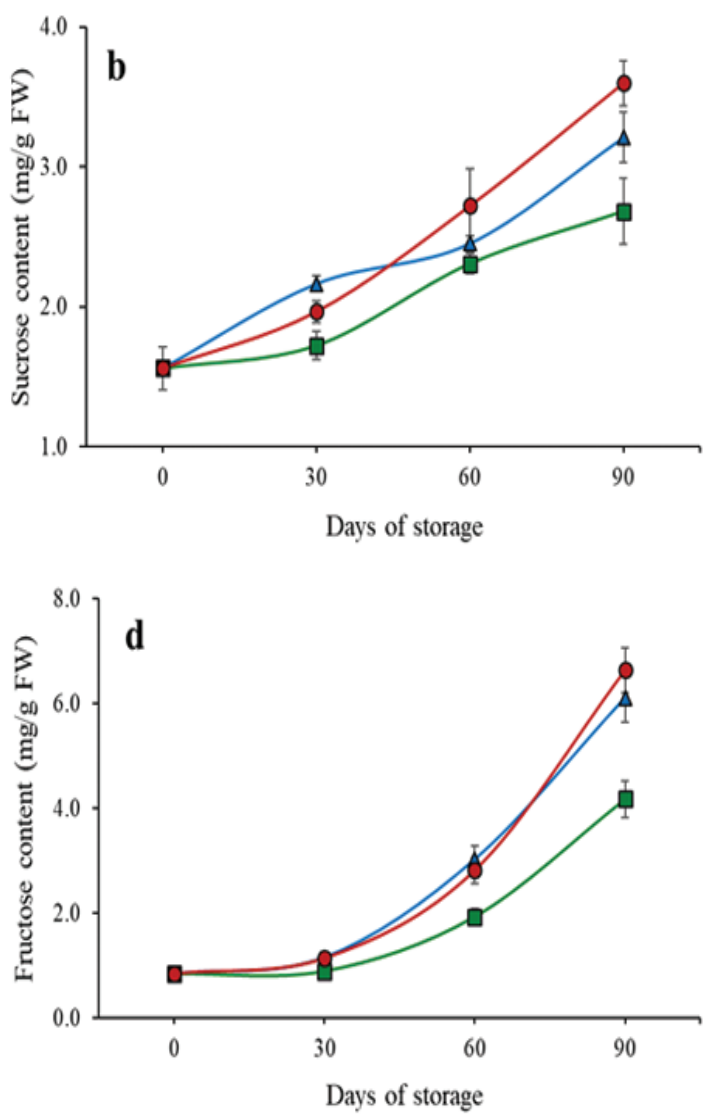

Fig. 4. Reducing sugars (a) sucrose, (b) glucose, (c) and fructose, (d) of three processing potato varieties in three storage conditions recorded at 30-day interval up to 90 days of storage. Means were calculated from three varieties with three replicates. Vertical bars represent the \pm SE values for the data point. 
in low temperature storage condition (RF) for all varieties. GLU is one kind of RS is produced by the breakdown of starch in very low temperature (Dogras et al., 1991) and therefore, GLU content of potato tubers was very high in $R F(1.01 \mathrm{mg} / \mathrm{g}$ at 90 days) (Fig 4c). Besides, the GLU content of potato tubers in $\mathrm{BC}$ was high compared to $\mathrm{EC}$, because the amount of GLU increased in potato tubers after prolonged storage at high temperature (Claassen et al., 1991). When glucose content of potato tubers exceeded $2.5 \%$ (above 0.25 $\mathrm{mg} / \mathrm{g} \mathrm{FW}$ ), the potato slices became colored and processing quality will be deteriorated (Gould and Plimpton, 1985). The processing quality of the tubers stored in $\mathrm{BC}$ and $\mathrm{RF}$ diminished before the 60 days' storage due to accumulation of more than $0.25 \mathrm{mg} / \mathrm{g} \mathrm{FW}$ GLU content (Fig 4c). On the contrary, potato tubers of EC retained the GLU content below $0.25 \mathrm{mg} / \mathrm{g} \mathrm{FW}$ up to the 60 days. So, EC was more suitable for storage of processing potato compared to other storages.

\section{Fructose content}

Potato tubers stored in the EC retained significantly lower mean fructose (FRU) content $(1.96 \mathrm{mg} / \mathrm{g} \mathrm{FW})$ than that of BC (2.78 $\mathrm{mg} / \mathrm{g} \mathrm{FW}$ ) and RF (2.86 mg/g FW) (Table 2). Among the potato varieties, Asterix showed significantly higher FRU content than those of Courage and Lady Rosetta in all three storage conditions. FRU content of potato tubers increased with storage time in all storage conditions (Fig 4d). The potato tubers of EC retained the lowest mean FRU content (4.11 mg/g FW) followed by BC $(6.11 \mathrm{mg} / \mathrm{g}$ FW) and RF (6.64 mg/g FW) at the 90 days of the storage period (Fig 4d). FRU being one kind of RS, will increase in long storage period both in very low temperature and high temperature (Dogras et al., 1991 and Claassen et al., 1991). Being a RS, FRU can participate in the Maillard reaction causing unacceptable browning of food products.

\section{Total soluble sugar content}

The mean total soluble sugars (TSS) of potato tubers was higher in RF $(5.83 \mathrm{mg} / \mathrm{g} \mathrm{FW})$ compared to $\mathrm{BC}(5.35 \mathrm{mg} / \mathrm{g} \mathrm{FW})$ and $\mathrm{EC}$ ( $4.20 \mathrm{mg} / \mathrm{g} \mathrm{FW}$ ) (Table 2). Among the potato varieties, Asterix showed significantly higher TSS content than that of Courage and Lady Rosetta in all three storage conditions. TSS content found to be increased in processing potato varieties with the advancement of storage period in all storage conditions (Fig 5a). Potato tubers stored in RF retained higher TSS content compared to $\mathrm{BC}$ and $\mathrm{EC}$ at all sampling dates because, the low temperature was responsible for the starch degradation into SUC due to inactivation of glycolytic enzymes and SUC is further hydrolyzed into GLU and FRU by the activity of enzyme invertase (Sonnewald, 2001). TSS content was higher in the $\mathrm{BC}$ compared to $\mathrm{EC}$ due to comparatively high temperature inside the chamber enhanced the solubility of the starch (Kaur et al., 2009). Therefore, EC was the suitable storage condition for the potatoes of processing purposes.

\section{Starch content}

Highest mean starch content (SC) was found in EC (99.91 mg/g FW) followed by RF (99.19 mg/g FW) and BC (98.69 mg/g FW) though the differences among them were not statistically significant (Table 2). Variety Asterix retained significantly lower mean SC content than Courage and Lady Rosetta 
in all storage conditions. SC of potato tubers declined in all storage conditions with the advancement of storage duration (Fig 5b). Similar decrease in the SC of ambient stored potatoes was reported by Pandey et al. (2017) and Bhattacharjee et al. (2014). The decrease in $\mathrm{SC}$ might be due to the increasing hydrolysis of SC by starch degrading enzyme (Cochrane et al., 1991) and its conversion into sugar (Smith, 1987) as storage duration was proceeded. Besides, the potato being an underground stem, the photosynthate, largely sucrose was stored in tubers as starch; some sucrose was also used for respiration and since this was a reversible process starch could also be converted back into sucrose at the storage (Olsen et al., 2005). During storage starch degradation occurs primarily through the action of starch phosphorylase and reducing sugars accumulate through various enzymatic reaction (Sowokinos, 1990). After 60 days of storage, the SC of potato tubers decreased rapidly in $\mathrm{BC}(92.81 \mathrm{mg} / \mathrm{g} \mathrm{FW}$ at 90 days) compared to EC (96.35 mg/g FW) and RF (94.24 mg/g FW) (Fig 5b). Potatoes stored in the $\mathrm{BC}$ lost $10.5 \% \mathrm{SC}$ at 90 days of storage in comparison with pre-storage $\mathrm{SC}$, whereas $\mathrm{EC}$ and RF lost 7.1 and 9.1\% SC, respectively. Thus, EC and RF were tended to be more efficient to maintain SC than BC. de Freitas et al. (2012) also found that lower storage temperatures $\left(4\right.$ and $\left.8^{\circ} \mathrm{C}\right)$ were more effective to maintain high SC.

\section{Sensory evaluation}

Sensory evaluation revealed that, chips produced from the potato tubers stored in the EC acquired significantly higher scores of sensory attributes compared to that of $\mathrm{BC}$ and RF (Table 3). The sensory characteristics like color, texture, taste, crispiness and overall acceptability are very good indicator for the preparation of good quality chips (Elfnesh et al., 2011). The poor color and taste scores in the chips produced from $\mathrm{BC}$ and $\mathrm{RF}$ were likely to be due to the reaction between the high RS and a free amino acid or amino group in the Maillard reaction (Fennema, 1996) and the formation of melanoidin pigments (Laerke and Christiansen, 2005). Among the varieties,

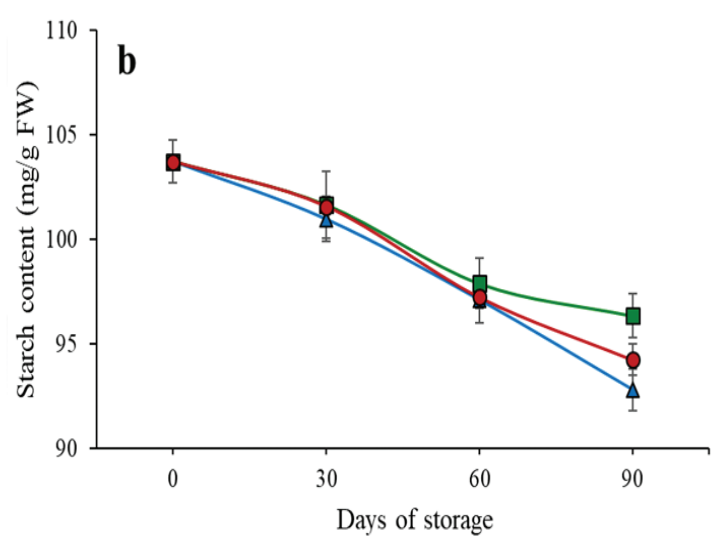

Fig. 5. Total soluble sugar (TSS) content (a) and starch content (b) of three processing potato varieties in three storage conditions recorded at 30-day interval up to 90 days of storage. Means were calculated from three varieties with three replicates. Vertical bars represent the \pm SE values for the data point. 
Table 3. Sensory evaluation of potato chips prepared after 90 days of storage from different potato varieties stored in different storage conditions

\begin{tabular}{llccccc}
\hline $\begin{array}{l}\text { Storage } \\
\text { condition }\end{array}$ & Variety & Color & Texture & Taste & Crispiness & $\begin{array}{c}\text { Overall } \\
\text { acceptance }\end{array}$ \\
\hline $\begin{array}{l}\text { Bamboo } \\
\text { chamber }\end{array}$ & Asterix & $3.8 \pm 0.13^{\mathrm{d}}$ & $3.4 \pm 0.16^{\mathrm{e}}$ & $4.3 \pm 0.15^{\mathrm{g}}$ & $3.2 \pm 0.13^{\mathrm{d}}$ & $3.2 \pm 0.13^{\mathrm{c}}$ \\
& Courage & $5.0 \pm 0.21^{\mathrm{b}}$ & $5.2 \pm 0.20^{\mathrm{c}}$ & $4.9 \pm 0.23^{\mathrm{ef}}$ & $4.8 \pm 0.20^{\mathrm{bc}}$ & $4.8 \pm 0.20^{\mathrm{b}}$ \\
& Lady Rosetta & $4.9 \pm 0.28^{\mathrm{bc}}$ & $4.8 \pm 0.13^{\mathrm{cd}}$ & $5.0 \pm 0.21^{\text {ef }}$ & $4.6 \pm 0.16^{\mathrm{c}}$ & $4.7 \pm 0.15^{\mathrm{b}}$ \\
& Mean & $4.6 \pm 0.38^{\mathrm{B}}$ & $4.5 \pm 0.55^{\mathrm{C}}$ & $4.7 \pm 0.22^{\mathrm{C}}$ & $4.2 \pm 0.50^{\mathrm{C}}$ & $4.2 \pm 0.52^{\mathrm{B}}$ \\
\hline Earthen & Asterix & $4.8 \pm 0.20^{\mathrm{bc}}$ & $4.6 \pm 0.16^{\mathrm{d}}$ & $5.2 \pm 0.13^{\mathrm{de}}$ & $3.7 \pm 0.15^{\mathrm{d}}$ & $3.6 \pm 0.16^{\mathrm{c}}$ \\
chamber & Courage & $7.3 \pm 0.21^{\mathrm{a}}$ & $7.5 \pm 0.17^{\mathrm{a}}$ & $6.3 \pm 0.26^{\mathrm{ab}}$ & $7.5 \pm 0.22^{\mathrm{a}}$ & $7.7 \pm 0.15^{\mathrm{a}}$ \\
& Lady Rosetta & $7.1 \pm 0.18^{\mathrm{a}}$ & $7.3 \pm 0.15^{\mathrm{a}}$ & $6.5 \pm 0.22^{\mathrm{a}}$ & $7.3 \pm 0.21^{\mathrm{a}}$ & $7.4 \pm 0.16^{\mathrm{a}}$ \\
& Mean & $6.4 \pm 0.80^{\mathrm{A}}$ & $6.5 \pm 0.94^{\mathrm{A}}$ & $6.0 \pm 0.40^{\mathrm{A}}$ & $6.2 \pm 1.23^{\mathrm{A}}$ & $6.2 \pm 1.31^{\mathrm{A}}$ \\
\hline Refrigerator & Asterix & $3.2 \pm 0.25^{\mathrm{e}}$ & $3.5 \pm 0.17^{\mathrm{e}}$ & $4.5 \pm 0.22^{\mathrm{fg}}$ & $3.6 \pm 0.22^{\mathrm{d}}$ & $3.3 \pm 0.15^{\mathrm{c}}$ \\
& Courage & $4.7 \pm 0.15^{\mathrm{bc}}$ & $6.5 \pm 0.17^{\mathrm{b}}$ & $5.8 \pm 0.20^{\mathrm{bc}}$ & $5.2 \pm 0.20^{\mathrm{b}}$ & $4.9 \pm 0.28^{\mathrm{b}}$ \\
& Lady Rosetta & $4.4 \pm 0.22^{\mathrm{c}}$ & $6.3 \pm 0.15^{\mathrm{b}}$ & $5.7 \pm 0.15^{\mathrm{cd}}$ & $5.1 \pm 0.23^{\mathrm{bc}}$ & $4.6 \pm 0.16^{\mathrm{b}}$ \\
& Mean & $4.1 \pm 0.46^{\mathrm{C}}$ & $5.4 \pm 0.97^{\mathrm{B}}$ & $5.3 \pm 0.42^{\mathrm{B}}$ & $4.6 \pm 0.52^{\mathrm{B}}$ & $4.3 \pm 0.49^{\mathrm{B}}$ \\
\hline & CV $(\%)$ & $12.25^{\circ}$ & 8.83 & 12.30 & 12.83 & 11.28 \\
\hline
\end{tabular}

Values and means in a column followed by same lowercase and uppercase letter(s), respectively are not statistically different at $p<0.05$ by Tukey's HSD test. Values are the average of 10 replicates.

chips produced from Courage and Lady Rosetta made comparatively higher scores in sensory attributes than Asterix in all storage conditions.

\section{Conclusions}

In the RF, the physical qualities (DM content, weight loss, shrinkage and energy content) of potato tubers remained optimum for the processing purposes. But in the refrigerated storage $\left(10-12^{\circ} \mathrm{C}\right)$, sugar contents of potato tubers increased markedly with the advancement of storage time and contributed to the dark chip color and lower acceptance in the sensory evaluation. Besides, this system is very high energy consuming and costly compared to other storage system. In the EC, the DM content $(\geq 20 \%)$, RS $(\leq 3.30$ $\mathrm{mg} / \mathrm{g} \mathrm{FW})$ and SUC $(\leq 2.80 \mathrm{mg} / \mathrm{g} \mathrm{FW})$ of potato tubers were within the desirable limit for processing up to the 90 days, whereas the potato tubers lost the processing quality after 60 days of storage in BC. Therefore, EC was more suitable for long-term storage of processing potatoes regarding tuber attributes and sensory evaluation. Besides, this system was economically feasible as it consumes low energy compared to RF. Variety Courage and Lady Rosetta were suitable for long-term storage for processing compared to Asterix as these varieties were able to maintain the desirable limit of physico-chemical processing qualities throughout the storage duration.

\section{Acknowledgements}

The authors sincerely acknowledge the Research Management Wing (RMW) of Bangabandhu Sheikh Mujibur Rahman 
Agricultural University, Bangladesh for the financial support to conduct the research. The authors also acknowledge the contribution of the Tuber Crops Research Center (TCRC) of Bangladesh Agricultural Research Institute (BARI) and Bangladesh Agricultural Development Corporation (BADC) for providing seed tubers for this research.

\section{References:}

Abano, E. E., E. Teye, R. S. Amoah and J. P. Tetteh. 2011. Design, construction and testing of evaporative cooling bran for storing sweets potatoes in the tropics. Asian Journal of Agricultural Research. 5(2): 115-126.

Adams, J. B. 2004. Raw materials quality and the texture of processed vegetables. Texture in Foods. Vol. 2, Pp. 342-363. D. Kilcast (ed) Solid Foods. Woodhead Publ. Ltd., Cambridge.

Addisu, S., G. Bultson and N. Dechassa. 2014. Effect of variety and storage on the tuber quality of potatoes cultivated in the eastern highlands of Ethiopia. Sci. Technol. Arts Res. J. 3(1): 84-89.

Adu-Kwarteng, E. E., O. Sakyi-Dawson, G. S. Ayernor, V. Truong, F. F. Shih and K. Daigle. 2014. Variability of sugars in staple-type Sweet Potato (Ipome batatus) cultivars: the effects of harvest time and storage. International Journal of Food Properties. 17: 410-420.

BAMD. 2018. Rangpur farmers storing potato in natural cold storages. Bangladesh Agricultural Marketing Department. Available via https://thefinancialexpress. com.bd/national/country/rangpurfarmers-storing-potato-in-natural-coldstorages-1527694886. Accessed on 27 December 2019.

Basediya, A. L., D. V. K. Samuel, and V. Beera. 2013. Evaporative cooling system for storage of fruits and vegetables - a review. J. Food Sci. Technol. 50(3): 429-442.

BBS. 2018. Yearbook of Agricultural Statistics of Bangladesh. 2018. Bangladesh Bureau of Statistics. Government of the People's Republic of Bangladesh.

Bhattacharjee, A., T. S. Roy, M. N. Haque, M. A. I. Pulok and M. M. Rahman. 2014. Changes of sugar and starch levels in ambient stored potato derived from TPS. International Journal of Scientific and Research Publications. 4(11): 1-5.

Blenkinsop, R. W., L. J. Copp, R. Y. Yada and A. G. Marangoni. 2002. Changes in compositional parameters of potato (Solanum tuberosum L.) during low temperature storage and their relationship to chip processing quality. J. Agric. Food Chem. 50(16): 4545-4553.

Bradbury, J. H. 1986. Determination of energy from moisture content in foods containing small amount of fat and dietary fiber. $J$. Agric. Food Chem. 34: 358-361.

Burton, W. G. 1966. The Potato: A survey of its history and factors influencing its yield, nutritive value, quality and storage. $382 \mathrm{P}$. Zonen, Wageningen. Holland.

Burton, W. G. 1973. Physiological and biochemical changes in the tuber as affected by storage conditions. Proceedings $5^{\text {th }}$ Triennial Conference of European Association of the Potato Research, Norwich. 63 P.

CIP. 2013. Innovative Potato Storage for Smallholder Farmer Households in Bangladesh. International Potato Center. Available via https://cipotato.org/potato/ innovative-potato-storage-for-smallholderfarmer-households-in-bangladesh/. Accessed on 27 December 2019.

Claassen, P. A. M., M. A. W. Budde, H. J. de Ruyter, M. H. van Calker and A. van Es. 
1991. Potential role of pyrophosphate: fructose 6-phosphate phospho-transferase in carbohydrate metabolism of cold stored tubers of Solanum tuberosum Bintje. Plant Physiology. 95: 1243-1249.

Cochrane, M. P., C. M. Duffus, M. J. Allison and G. R. Mackay. 1991. The effect of low temperature storage on the activities of alpha and beta amylase and alpha glycosidase in potato tubers. J. Potato Res. 34 (4): 333-341.

Dadhich, S. M., H. Dadhich and R. C. Verma. 2008. Comparative study on storage of fruits and vegetables in evaporative cool chamber and in ambient. Int. J. Food Eng. 4(1): 1-11.

Davies, H. V., R. Viola. 1992. Regulation of sugar accumulation in stored potato tubers. Postharvest News Inf. 3(5): 97-100.

de Freitas, S. T., E. I. P. Pereira, A. C. S. Gomez, A. Blackmann, F. Nicolson and D. A. Bisognin. 2012. Processing quality of potato tubers produced during autumn and spring and stored at different temperatures. Horticultura Brasileira. 30(1): 91-98.

Dogras, C., A. Siomos and C. Psomakells. 1991. Sugar and dry matter changes in potatoes stored in a clamp in mountainous region of northern Greece. Potato Research. 34: 211214.

Edwards, C. G., J. W. Engle, C. R. Brown, J. C. Peterson and E. J. Sorensen. 2002. Changes in colour and sugar content of yellowfleshed potatoes stored at three different temperatures. American Journal of Potato Research. 79: 49-53.

Elfnesh, F., T. Tekalign and W. Solomon. 2011. Processing quality of improved potato (Solanum tuberosum L.) cultivars as influenced by growing environment and blanching. African J. Food Sci. 5: 324-332.
Ezekiel, R., B. Singh, D. Kumar and A. Mehta. 2007. Processing quality of two potato varieties grown at two locations and stored at 4,10 and $12^{\circ}$ C. Potato Journal. 34: 164173.

Fennema, O. R. 1996. Food Chemistry. Third Edition. Marcel Dekker Inc. New York.

Gottschalk, K. and R. Ezekiel. 2006. Storage. Pp. 489-522. In Handbook of Potato Production, Improvement, and Postharvest Management. Food Products Press, New York-London-Oxford.

Gould, W. A. and S. Plimpton. 1985. Quality evaluation of potato cultivars for processing. Research publication 305 , The Ohio State University.

Hossain, M. A. and M. A. M. Miah. 2009. Postharvest losses and technical efficiency of potato storage systems in Bangladesh. Final Report, National Food Policy Capacity Strengthening Programme (NFPCSP). 1 P.

Huang, Y. H., D. H. Picha, A. W. Kilili and C. E. Johnson. 1999. Changes in invertase activities and reducing sugar content in sweet potato stored at different temperatures. J. Agric. Food Chem. 47: 4927-4931.

Isherwood, F. A. 1973. Mechanism of Starch-Sugar inter-conversion in Solanum tuberosum. Phytochemistry. 12: 2579-2591.

Jha, S. N. and S. Chopra. 2006. Selection of bricks and cooling pad for construction of evaporatively cooled storage structure. Inst. Engineers. (I) (AG) 87: 25-28.

Kabira, J. and L. Berga. 2003. Potato processing quality evaluation procedure for research food industry applications in east and central Africa. Kenya Agric. Res. Insti., Nairobi.

Kadam, S. S., S. S. Dhumal and N. D. Jambhale. 1991. Structure, nutritional composition, 
and quality. Pp. 9-36. In: D. K. Salunkhe, et al. (ed.) Potato: Production, Processing, and Products. CRC Press. Boca Raton.

Kang, M. R., M. M. Hanafi, S. M. Shahidullah, A. H. M. A. Rahman, A. M. Akanda and A. Khair. 2009. Virus free seed potato production through sprout cutting technique under net-house. African Journal of Biotechnology. 9(36): 5852-5858.

Kaur, A., N. Singh, R. Ezekiel and N. S. Sodhi. 2009. Properties of starches separated from potatoes stored under different conditions. Food Chemistry. 114: 1396-1404.

Kita, A., A. Bąkowska-Barczak, G. Lisińska, K. Hamouz, and K. Kułakowska. 2014. Antioxidant activity and quality of red and purple flesh potato chips. Food Science and Technology. 62(1): 525-531.

Laerke,P. E. and J.Christiansen. 2005.Identification of pre-harvest biomarkers in potato (Solanum tuberosum L.) for improvement of the post-harvest management of frycolour. Acta Horticulturae. 682: 493-499.

Lisinski, G. and W. Leszczynski. 1989. Potato tubers as a raw material for processing and nutrition. In G. Lisinski and W. Leszczynski (ed) Potato Science and Technology. Department of Storage and Food Technology. Agricultural Academy, Wroclaw, Poland.

Mehta, H. and H. N. Kaul. 1988. High temperature storage of potato (Solanum tuberosum L.) for processing - a feasibility study. Plant Foods for Human Nutrition. 38: 263-268.

Meilgaard, M., G. V. Civile, and B. T. Carr. 2007. Sensory Evaluation Techniques. 4th Edition. CRC Press. Florida, USA.

Miller, G. L. 1959. Use of dinitrosalicylic acid reagent for determination of reducing sugar. Annals of Chemistry. 31 (3): 426-428.
Olsen, N., G. Kleinkopf, L. Woodell and T. Brandt. 2005. Processing quality: Cultivars, vine kill and storage. Presented at the Idaho Potato Conference.

Pandey, V., V. A. Kumar and A. Brar. 2017. Biochemical Behaviour of Potato Tubers during Storage. Chem. Sci. Rev. Lett. 6(23): $1818-1822$

Perumal, N. K., K. R. Dhiamn, and T. A. Sahota. 1980. Dormancy and sprouting behavior of some Indian cultivars and cultures of potato. Bangladesh Hort. 8: 1-7.

Rommens, C. M., R. Shakya, M. Heapand and K. Fessenden. 2010. Tastier and healthier alternatives to French Fries. Journal of Food Science. 75: 109-115.

Schippers, P. A. 1971. The relation between storage conditions and changes in weight and specific gravity of potatoes. American Potato Journal. 48: 313-319.

Senkumba, J., A. Kaaya, A. Atukwase, and A. Wasukira. 2017. Technical Report: Effect of storage conditions on the processing quality of different potato varieties grown in Eastern Uganda. CRP, RTB. 22 P.

Smith, O. 1987. Effect of cultural and environmental conditions on potato processing. Pp.73-74. In W.F. Talburt and O. Smith (ed) Potato Processing. Van Reinhold Company. New York.

Sonnewald, S. and Sonnewald, U. 2014. Regulation of potato tuber sprouting. Planta. 239: 2738.

Sonnewald, U. 2001. Control of potato tuber sprouting. Trends Plant Sci. 6: 333-335.

Sowokinos, J. R. 1990. Stress induced alteration in carbohydrate metabolism. Pp. 137- 158. In The Molecular and Cellular Biology of the Potato. Wallingford, UK. 
Sowokinos, J. R., P. H. Orr, J. A. Knoper and J. L. Varns, 1987. Influence of potato storage and handling stress on sugars, chip quality and integrity of the starch (amyloplast) membrane. American Potato Journal. 64: 213-226.

Tester, R. F., R. Ansell, C. E. Snape and M. Yusuph. 2005. Effect of storage temperatures and annealing conditions on the structure and properties of potato (Solanum tuberosum L.) starch. Intl. J. Biol. Macromol. 36: 1-8.

Timm, H., M. Yamaguchi, M. D. Clegg and J. C. Bishop. 1968. Influence of high temperature exposure on sugar content and chipping quality of potatoes. America Potato Journal. 45: 359-365.
Wiltshire, J. J. and A. H. Cobb. 1996. A review of the physiology of potato tuber dormancy. Annals Appl. Biol. 129: 553-569.

Work, T. M., A. S. Kezis and R. H. True. 1981. Factors determining potato chipping quality. Technical Bulletin 103, Life sciences and agriculture experiment station, University of Maine at Orono.

Xue, L. 1985. A handbook of Experiments for plant physiology. Shanghai Science and Technology, Shanghai.

Zhitain, Z., C. C. Wheatley and H. Corke. 2002. Biochemical changes during storage of sweet potato roots differing in dry matter content. J. Postharvest Biol. Technol. 24: 317-325. 